\title{
Reinventing Konsep Muhkam-Mutasyābih dan Pengembangannya dalam Tafsir al-Qur'an Kontekstual
}

Ahmad Syaifuddin Amin

UIN Syarif Hidayatullah, Indonesia

saifuddinamin.ahmad@gmail.com

\begin{abstract}
Discourse of Muhkām-Mutasyābih which has been discussed in the classical literatures of ulūm al-Qur'ān was getting worse because of some shift meanings especially specialization that limits muhkām-mutasyābih discussion on the teological verses of the Quran. The lack of discussion and elaboration on muhkam-mutasyābih in interpreting Quran worsens this situation. The effort to reframe this specialization among classical scholars and the reinventing concept of muhkam-mutasyābih could open prospective ways to elaborate this discourse and other approapches in Quranic exegesis. By inventarizing some concepts of muhkam-mutasyābih initiated by Islamic Scholars and considering them by interpretation rules, this article concludes that some muhkam-mutasyābih concepts of the scholars should be considered and elaborated in interpreting Quran. As a consequence of diversable interpretation of Quran, This various concepts of muhkam-mutasyābih should be expanded to the interpretation of the Quran for constructing contextual interpretation of the Quran keeping the balance of textual values and answering human needs of Quranic Solution for their problems.
\end{abstract}

Keywords: reinventing, muhkam, mutasyābih, interpretation, contextual

Abstrak: Diskursus muhkam-mutasyābih yang telah berkembang sejak masa penulisan ilmu al-Qur'an klasik namun justru mengalami penyempitan makna yang tidak seharusnya terjadi. Penyempitan makna (spesialisasi) itu nampak dari minimnya pembahasan muhkam-mutasyābih pada selain ayat-ayat teologis dan minimnya elaborasi saat proses interpretasi al-Qur'an. Upaya reframing terhadap spesialisasi yang terjadi dengan diiringi upaya reinventing konsep muhkam-mutasyābih menjadi pembuka peluang elaborasi konsep muhkam-mutasyābih dengan berbagai konsep bahkan disiplin ilmu lain. Dengan melakukan reinventarisasi terhadap konsep para ulama tentang muhkam-mutasyābih kemudian menimbangnya dengan kaidah tafsir, dihasilkan kesimpulan bahwa terdapat banyak konsep muhkam-mutasyābih di kalangan ulama yang seharusnya bisa dielaborasi dan dipakai dalam penafsiran alQur'an. Perbedaan konsep tersebut merupakan bagian dari konskuensi tanawwu' dalam interpretasi al-Qur'an yang seharusnya tidak dicampakkan begitu saja. Pengembangan konsep muhkam-mutasyābih dengan melibatkan maqāṣīd syarī'ah dan komponen lainnya mendukung dan meneguhkan eksistensi tafsir kontekstual yang tetap seimbang dalam menjaga kehormatan teks serta menjawab kebutuhan umat terhadap tafsir alQur'an.

Kata Kunci: reinventing, muhkam, mutasyābih, tafsir, kontekstual. 


\section{Pendahuluan}

Salah satu konsep mendasar dalam 'ulūm al-Qur'ān yang justru sering diabaikan dalam interpetasi al-Qur'an adalah kosep tentang Muhkām dan Mutasyābih. Berbeda dengan beberapa konsep dalam 'ulūm al-Qur'ān lain yang lahir seiring dengan uṣūl alfiqh,- seperti mujmāl-mubayyan, '̌am-khās, manțūq-mafhūm dan konsep-konsep lainnya. ${ }^{1}$ Muhkām-Mutasyābih muncul lebih awal karena memang keduanya disebutkan secara eksplisit dalam al-Qur'an sehingga komentar-komentar terhadap makna muhkāmmutasyābih banyak ditemui sejak masa pewahyuan al-Qur'an baik riwayat dari kalangan sahabat maupun riwayat yang disandarkan kepada Rasulullah SAW langsung. Terlepas dari berbagai status validitas Riwayat-riwayat yang ada, para pakar 'ulüm al-Qur'an sejak masa klasik hingga kontemporer masih menggunakan riwayat-riwayat komentar tersebut.

Konsep muhkām-mutasyābih tentu tidak bisa diabaikan dalam proses interpretasi al-Qur'an karena memang klasifikasi itu termaktub langsung dalam teks al-Qur'an QS. Ali Imran [3]:7 , artinya klasifikasi muhkām-mutasyābih bukanlah suatu hasil penafsiran yang zann̄̄ melainkan bagian yang qaț'̄i jika ditinjau dari segi validitas teksnya (al-wurūd/ altsubūt). ${ }^{2}$ Layaknya ayat-ayat lain, dalam literatur tafsir bi al-ma'tsūr banyak ditemukan riwayat-riwayat tafsir ayat ini, baik yang berkenaan dengan definisi muhkām-mutasyābih sendiri, maupun sikap orang mukmin dalam berinteraksi dengan muhkām-mutasyābih. Tafsir dan pemahaman terhadap QS. Ali Imran [3]:7 ini pun berkembang seiring dengan perkembangan 'ulūm al-Qur'ān yang relatif lebih akhir daripada disiplin ilmu lain seperti ilmu hadits, ilmu fikih maupun ushul fikih.

Perkembangan diskursus muhkām-mutasyābih sebenarnya telah muncul sejak awal sejarah 'ulūm al-Qur'ān itu sendiri. Hal ini dibuktikan dengan banyaknya riwayat yang dikutip oleh para pelopor penulis karya di bidang 'ulūm al-Qur'ān seperti al-Zarkasyī ${ }^{3}$ dan al-Suyūțît yang tidak hanya bersumber dari Rasulullah, kalangan sahabat maupun tābi' în tetapi keduanya telah mengutip pendapat ulama yang datang lebih akhir dari abad tiga

\footnotetext{
${ }^{1}$ Mannā’ Khalīi al-Qaț̣ān, Tārikh al-Tasyrī' al-Islāmi (Kairo: Maktabah Wahbah, 1420), 370.

${ }^{2}$ Teks agama berdasarkan validitas teksnya menurut para ahli uṣūl diklasifikasikan menjadi dua yaitu

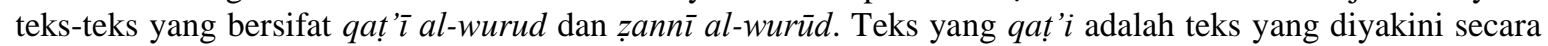
pasti validitas teksnya karena diriwayatkan oleh segolongan orang yang tidak mungkin sepakat berbohong dari generasi ke generasi (Mutawātir). Teks ini meluputi al-Qur'an, hadits mutawātir dan ijma'. Sedangkan teks agama lain bersifat zann̄ , tidak diyakini secara pasti validitas teksnya karena periwayatnnya melalui jalur āhāàd (tidak mencapai mutawātir). Abd al-Wahab Khalāf, Ilmū Ușūl al-Fiqh wa Khulāṣah Tārīkh alTasyrī' (Mesir: Mațba'ah al-Madani, 1999), 35.

${ }^{3}$ Badr al-Dīn al-Zarkasyī, al-Burhān fì 'Ulūm al-Qur'ān (Beirut: Dār Iḥyā' al-Kutub al-'Arabīyah 'Isā al-Bābi al-Halbī, 1957), 70.

${ }^{4}$ Jalal al-Dīn al-Suyūṭị, Al-Itqān fì 'Ulūm al-Qur'ān (Beirut: Dār al-Kutub al-Alamiyah, 2012), 309.
} 
hingga lima Hijriyah. Fakta ini menunjukkan dinamisasi pemaknaan konsep muhkāmmutasyābih telah ada sejak masa klasik, namun sayangnya di saat yang sama justru tidak mendapatkan perhatian yang proporsional dalam pengembangan ulūm al-Qur'ān .

Kajian terhadap konsep muhkam-mutasyābih dalam wacana tafsir al-Qur'an kontemporer juga terhitung statis dibandingkan dengan konsep-konsep lain yang digunakan sebagai perangkat penafsiran. Salah satu penelitian yang relatif berbeda dengan penelitian lain adalah penelitian tentang konsep muhkām-mutasyābih menurut Muhammad 'Abid al-Jabiri yang menghasilkan kesimpulan bahwa ia menawarkan dua cara untuk mentakwil ayat-ayat mutasyābih yaitu dengan cara memperhatikan siyaq (konteks pembicaraan ayat) dan asbāb al-Nuzūl..$^{5}$ Adapun penelitian lain tentang muhkāmmutasyābih masih sebatas tentang konsep umum, perbedaan sikap (takwil) dan hikmah eksistensi muhkām-mutasyābih dalam al-Qur'an.

Berangkat dari permasalahan di atas, penulis berupaya untuk melakukan reinventing ${ }^{6}$ konsep muhkām-mutasyābih yang telah ada sejak masa klasik itu untuk mewacanakan pengembangan konsep muhkām-mutasyābih. Reinventarisir ini menjadi langkah awal yang penting untuk membuka peluang muhkām-mutasyābih agar dikaji dan dikembangkan dalam penafsiran al-Qur'an. Dengan mengkaji literatur pustaka yang ada (library research) penulis menggunakan metode analisis deskriptif dengan bantuan kaidahkaidah tafsir untuk menimbang kemungkinan pengembangan konsep muhkām-mutasyābih. Upaya reinventing ini diharapkan menjadi salah satu solusi pengembangan tafsir alQur'an kontekstual sehingga konsep tersebut dapat ditempatkan pada posisi yang lebih luas sebagaimana mestinya demi menampilkan wajah al-Qur'an sebagai kitab yang șālih li kulli makān wa zamān.

\section{Konsep Muhkām-Mutasyābih dalam Literatur `Ulūm al-Qur'an Klasik}

Konsep muhkām-mutasyābih berawal dari ayat berikut:

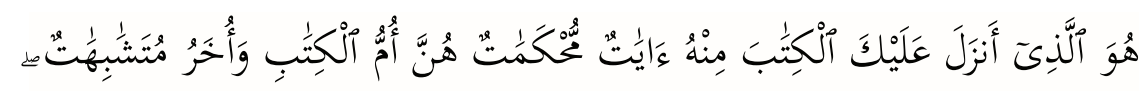

\footnotetext{
${ }^{5}$ Miftahur Rahman, “(PDF) Konsep Muhkam Dan Mutasyabih Dalam Alqur'an Menurut Muhammad 'Abid al-Jabiri," Hermeneuti: Jurnal Ilmu Al-Qur'an Dan Tafsir 12 (2018): 182, https://doi.org/DOI: 10.21043/hermeneutik.v12i1.6072.

${ }^{6}$ Reinventing berarti menggali sesuatu yang telah lama ada untuk memproduksi sesuatu yang baru. "REINVENT | Meaning in the Cambridge English Dictionary," diakses 25 September 2020, https://dictionary.cambridge.org/dictionary/english/reinvent.
} 
"Dialah yang menurunkan Al Kitab (Al Quran) kepada kamu. Di antara (isi)nya ada ayat-ayat yang muhkamāt, itulah pokok-pokok isi Al qur'an dan yang lain (ayat-ayat) mutasyābih. (QS. Ali Imran [3]: 7)

Secara etimologis, kata muhkam berarti $\mathrm{kuat}^{7}$, sempurna dan tidak memiliki kemiripan $^{8}$, sedangkan kata mutasyābih berasal dari kata syabah yang berarti kemiripan dan keserupaan. ${ }^{9}$ Adapun secara terminologis, muhkam-mutasyābihat memiliki sekian pemaknaan berdasarkan perkembangan ulüm al-Qur'ān .

Perkembangan 'Ulūm al-Qur'ān sebagai suatu disiplin khusus terhitung terlambat jika dibandingkan dengan disiplin ilmu lain seperti fikih, uṣūl al-fiqh, ilmu hadits dan beberapa ilmu lain. Bahkan istilah 'ulūm al-Qur'ān sendiri tidak dikenal pada masa awal pertumbuhan Islam. ${ }^{10}$ Berdasarkan catatan al-Zarqāni, Literatur pertama yang menggunakan istilah ini baru muncul pada pertengahan abad keempat oleh al-Ḥūî̀ dengan karyanya al-Burhān fì 'Ulūm al-Qur'ān, namun sayangnya kitab tersebut pun tidak ditemukan salinan lengkapnya serta lebih mirip seperti kitab tafsir. Kendati demikian, nama al-Ḥūfi seringkali disebut sebagai tokoh pertama yang membukukan ulūm alQur'ān. ${ }^{11}$ Walaupun telah dikenal sejak abad keempat Hijriyah, istilah 'Ulūm al-Qur'ān baru populer pada abad ketujuh Hijriyah. Namun baru pada abad ke delapan hingga sepuluh Hijriyah, terhitung marak penulisan karya-karya dalam disiplin ini dengan terbitnya sejumlah karya populer yang memang khusus membahas berbagai bab tentang ‘ulūm al-Qur'ān. ${ }^{12}$ Salah satu ulama yang menulis perkembangan 'ulūm al-Qur'ān dengan cukup detil adalah al-Zarqāni. Ia menginventarisir literatur 'ulūm al-Qur'ān yang representatif pada setiap masa. Diantara karya-karya 'ulüm al-Qur'ān yang disebutkan alZarqāni dalam historisasi disiplin 'ulūm al-Qur'ān adalah Funūn al-Afnān fì 'Ulūm alQur'ān karya Ibn al-Jawzī (w. 597 H), Jamāl al-Qurrā' karya al-Sakhāwi (w. 641 H), alMursyid al-Wajīz ilā 'Ulūm Tata'allaq bi al-Kitāb al- 'Azīz karya Abū Syāmah (w. 665), al-Burhān fì 'Ulūm al-Qur'ān karya al-Zarkasyi (w. 794 H), Mawāqi' al- 'Ulūm fi Mawāqi'

\footnotetext{
${ }^{7}$ Ahmad Warson Munawwir, Kamus Al-Munawwir (Surabaya: Pustaka Progresif, 1997), 286.

${ }^{8}$ Ibrahim Mushtafa Ahmad Zayyat, Al-Mu'jam al-Wasīt (Kairo: Dar al-Da'wah, t.t.), 190.

${ }^{9}$ Majd al-Dīn al-Fairuz Abādī, Bașā'ir dzawi al-tamyīz fì Lațā'if al-Kitāb al- 'Azīz (Kairo: Lajnah Ihyā' al-Turāts al-Islāmī, 1996), 293.

10 M. Saifulloh Wahyuddin, "Ulum al-Qur'an Sejarah dan Perkembangannya," Jurnal Sosial Humaniora, 1, 6 (Juni 2013): 25, DOI: 10.12962/j24433527.v6i1.608.

${ }^{11}$ Mannā' Khalīl al-Qațtān, Mabāhīts fì 'Ulūm al-Qur'ān (Kairo: Maktabah al-Ma'ārif, 2000), 10.

${ }^{12}$ Muhammad Abd al-Ạ̄īm al-Zarqānī, Manāhil Al- 'Irfān F̄̄ 'Ulūm al-Qur'ān (Beirut: Maṭba'ah Isa al-Babi al-Halabi, 2000), 34.
} 
al-Nujūm karya al-Bulqīni (w. 824 H) dan al-Itqān fì 'Ulūm al-Qur'ān karya al-Suyūṭ̂̄ (w. $911 \mathrm{H}) \cdot \cdot^{13} \mathrm{~s}$

Dari sekian kitab yang disebutkan oleh al-Zarqāni, ternyata pembahasan khusus tentang konsep muhkām-mutasyābih tidak ditemukan dalam Jamāl al-Qurrāa ${ }^{, 14}$ karya alSakhāwi (w. 641 H), al-Mursyid al-Waj̄̄z ilā 'Ulūm Tata'allaq bi al-Kitāb al-'Azīz karya Abū Syāmah (w. 665) ${ }^{15}$ dan Mawāqi' al- 'Ulūm fi Mawāqi' al-Nujūm karya al-Bulqīni (w. $824 \mathrm{H})^{16}$. Konsep mutasyābih mulai menjadi pembahasan khusus pada Funūn al-Afnān fì 'Ulūm al-Qur'ān karya Ibn al-Jawzī (w. 597 H). Namun sayangnya pembahasan mutasyābih dalam kitab ini bukan pada konteks mutasyābih yang ada pada QS. Ali Imran [3]: 7, tetapi lebih kepada mutasyābih laf̧̧iyah yang termaktub dalam al-Qur'an:

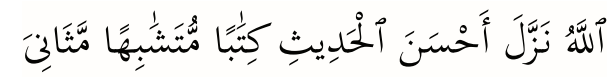

"Allah telah menurunkan perkataan yang paling baik (yaitu) Al Quran yang serupa (mutasyābih) lagi berulang-ulang” (QS. Al-Zumar [39]: 23)

Mutasyābih pada ayat diatas diinterpretasikan sebagai tasyābuh ‘ām,- keserupaan yang umum artinya semua ayat al-Qur'an serupa dari segi kesempurnaan dan keindahan lafazh serta maknanya. ${ }^{17}$ Keserupaan pertama (lafadz) inilah yang dibahas oleh Ibn alJawzì dalam Funūn al-Afnān fì 'Ulūm al-Qur'ān sehingga tidak berkaitan dengan konsep muhkām-mutasyābih yang ada di QS. Ali Imran [3]:7.

Diskursus muhkām-mutasyābih baru benar-benar mendapatkan perhatian pada dua karya besar dalam disiplin 'ulūm al-Qur'ān, yaitu al-Burhān fì 'Ulūm al-Qur'ān dan alItqān fì 'Ulūm al-Qur'ān. Kedua karya yang kemudian menjadi kiblat utama karya-karya setelahnya ini menjadikan pembahasan muhkām-mutasyābih sebagai bab tersendiri dalam kitab tersebut. Al-Suyūṭi menyebutkan setidaknya ada tiga belas perbedaan ulama mengenai definisi muhkām-mutasyābih. Delapan dari tiga belas definisi tersebut tidak ia

\footnotetext{
${ }^{13}$ Muhammad Abd al-Aẓ̄m al-Zarqān̄̄, Manāhil Al- 'Irfān Fì 'Ulūm al-Qur'ān (Beirut: Maṭba'ah Isa al-Babi al-Halabi, 2000), 37. 1997).

${ }^{14}$ Abu al-Hasan al-Sakhāwī, Jamāl al-Qurrā' wa Kamāl al-Iqrā' (Beirut: Dār al-Ma'mūn li al-Turāts,

${ }^{15}$ Abū Syāmah, al-Mursyid al-Waj̄̄z ilā 'Ulūm Tata'allaq bi al-Kitāb al- 'Azīz (Beirut: Dār Shadir, 1975), 287.

${ }^{16}$ Jalal al-Dīn al-Bulqīnī, Mawāqi' al- 'Ulūm fi Mawāqi' al-Nujūm (Ṭanța: Dār al-Ṣahāābah li al-Turāts, 2007), 190.

17 Fikria Najitama, "Diskursus Muhkam dan Mutasyabih dalam Tafsir," An-Nidzam: Jurnal Manajemen Pendidikan dan Studi Islam 4, no. 1 (2017): 157.
} 
sebutkan riwayatnya, sedangkan lima pendapat terakhir ia sandarkan secara urut kepada Ibnu Abbās, Mujāhid, al-Rabī̄, Muqātil dan Ikrimah.

Berikut adalah tabel definisi-definisi Muhkām-Mutasyābih yang dikutip al-Suyūṭ̂1 ${ }^{18}$ :

\begin{tabular}{|c|c|c|}
\hline Pendapat ke & Muhkām & Mutasyābih \\
\hline 1 & $\begin{array}{l}\text { Sesuatu yang diketahui } \\
\text { maknanya baik dengan zāhir } \\
\text { ataupun takwil }\end{array}$ & $\begin{array}{l}\text { Sesuatu yang maknanya } \\
\text { disimpan oleh Allah SWT } \\
\text { seperti waktu terjadinya kiamat }\end{array}$ \\
\hline 2 & Sesuatu yang jelas maknanya & $\begin{array}{l}\text { Sesuatu yang tidak jelas } \\
\text { maknanya }\end{array}$ \\
\hline 3 & $\begin{array}{l}\text { Sesuatu yang hanya memiliki } \\
\text { satu takwil, tidak } \\
\text { memungkinkan ditakwil dengan } \\
\text { selainnya }\end{array}$ & $\begin{array}{l}\text { Sesuatu yang memiliki banyak } \\
\text { takwil }\end{array}$ \\
\hline 4 & $\begin{array}{l}\text { Sesuatu yang maknanya bisa } \\
\text { dilogiskan }\end{array}$ & $\begin{array}{l}\text { Sesuatu yang tidak bisa } \\
\text { dilogiskan maknanya }\end{array}$ \\
\hline 5 & $\begin{array}{l}\text { Sesuatu yang (pemahamannya) } \\
\text { bisa berdiri sendiri }\end{array}$ & $\begin{array}{l}\text { Sesuatu yang tidak bisa } \\
\text { dimaknai tanpa memahami } \\
\text { yang lainnya }\end{array}$ \\
\hline 6 & $\begin{array}{l}\text { Sesuatu yang takwilnya telah } \\
\text { diturunkan juga bersamanya } \\
\text { (ayat atau riwayat lain) }\end{array}$ & $\begin{array}{l}\text { Sesuatu yang tidak bisa } \\
\text { difahami tanpa ditakwil }\end{array}$ \\
\hline 7 & $\begin{array}{l}\text { Sesuatu yang terulang-ulang } \\
\text { redaksinya }\end{array}$ & $\begin{array}{l}\text { Sesuatu yang hanya disebutkan } \\
\text { sesekali saja }\end{array}$ \\
\hline 8 & $\begin{array}{l}\text { Terdiri dari kewajiban- } \\
\text { kewajiban, janji dan ancaman }\end{array}$ & $\begin{array}{l}\text { Terdiri dari kisah-kisah dan } \\
\text { perumpamaan }\end{array}$ \\
\hline 9 & $\begin{array}{l}\text { Nāsikh, Halal-haram, batasan- } \\
\text { batasan, kewajiban-kewajiban } \\
\text { serta hal yang tidak cukup } \\
\text { diimani tapi juga harus } \\
\text { diamalkan. }\end{array}$ & $\begin{array}{l}\text { Mansūkh, Muqaddam- } \\
\text { muakhkhar, amtsāl, aqsām, dan } \\
\text { segala sesuatu yang cukup } \\
\text { diimani saja tanpa perlu } \\
\text { diamalkan }\end{array}$ \\
\hline 10 & Perintah dan larangan & $\begin{array}{l}\text { Permulaan beberapa surat } \\
\text { (Fawātih al-Suwar) }\end{array}$ \\
\hline 11 & $\begin{array}{l}\text { Sesuatu yang menjelaskan halal- } \\
\text { haram }\end{array}$ & $\begin{array}{l}\text { Segala yang membahas selain } \\
\text { halal-haram }\end{array}$ \\
\hline 12 & Sesuatu yang tidak dinasakh & Sesuatu yang telah dinasakh \\
\hline 13 & Sesuatu yang harus diamalkan & $\begin{array}{l}\text { Sesuatu yang cukup diimani } \\
\text { tanpa harus diamalkan }\end{array}$ \\
\hline
\end{tabular}

Tabel yang menampilkan berbagai pemaknaan muhkām-mutasyābih versi al-Itqān di atas menunjukkan bahwa sebenarnya dinamisasi pemaknaan muhkām-mutasyābih telah terjadi sejak awal-awal Islam. Lima riwayat terakhir pada tabel di atas diriwayatkan oleh generasi-generasi awal baik dari kalangan sahabat maupun tābi'īn. Lebih lanjut,

\footnotetext{
${ }^{18}$ al-Suyūṭ̂, Al-Itqān fì 'Ulüm al-Qur'ān, 310.
} 
perdebatannya pun ternyata bukan lagi pada tataran istilah saja, tetapi benar-benar pada tataran substansi. Sebagai contoh misalnya definisi nomor sembilan pada tabel di atas sudah tidak lagi menyebut definisi secara normatif tapi sudah menampilkan bagian lebih detil daripada definisi sebelumnya yang cenderung lebih general.

Perbedaan yang juga sangat mencolok misalnya terjadi antara definisi pertama dan ke enam. Pada definisi pertama mutasyābih diasumsikan sebagai sesuatu yang "tidak tersentuh" tetapi di definisi nomor enam justru mutasyābih harus ditakwil agar dapat difahami. Adapun beberapa definisi juga mengaitkan muhkam-mutasyābih dengan konsep lain baik dalam disiplin 'ulūm al-Qur'ān, ușūl, hingga fiqh. Unsur-unsur yang berkaitan dengan 'ulūm al-Qur'ān seperti amtsāl, qașaș, muqaddam, muakhhar dan fawātih alsuwar sedangkan unsur-unsur yang tidak terlepaskan dari ușül misalnya nāsikh-mansūkh dan zāhir-nash. Adapun halal-haram tentu bagian dari definisi yang sangat berkaitan erat dengan fiqh/ahkäm.

Diskurus yang terekam dalam al-Itqān ini tentu bukan sesuatu yang tidak pernah ditulis oleh ulama sebelum al-Suyūṭ̂. Al-Zarkasȳ̄ sebagai pendahulunya yang juga memiliki karya besar dalam 'ulūm al-Qur'ān juga mengutip sejumlah definisi muhkāmmutasyābih. Di samping karya-karya 'ulūm al-Qur'an yang memang lahir lebih akhir, karya-karya di bidang uṣūl, hadits dan tafsir juga telah memuat konsep muhkāmmutasyābih lebih awal misalnya Al-Ṭabari yang mengutip sembilan belas riwayat penafsiran tentang makna muhkam-mutasyābih saat menginterpretasikan QS. Ali Imra [3]: 7. ${ }^{19}$ Al-Ṭabari yang merupakan pelopor tafsir bi al-ma'tsūr dalam interpretasi al-Qur'an ${ }^{20}$ tentu menggunakan riwayat-riwayat dari para pendahulunya dalam menafsirkan konsep muhkām-mutasyābih di ayat tersebut. Dengan demikian, konsep muhkām-mutasyābih memang memiliki pemaknaan dan interpretasi yang luas sejak kalangan mutaqaddimīn.

\section{Menimbang Posisi Penafsiran Muhkām-Mutasyābih dan Spesialisasi Maknanya}

Inventarisasi definisi muhkām-mutasyābih pada literatur-literatur klasik memang menunjukkan bahwa diskursus muhkām-mutasyābih sebenarnya telah dikenal bahkan diperdebatkan sejak generasi awal Islam. Namun begitu disayangkan, ternyata diskursus muhkām-mutasyābih ini justru menjadi terbatas karena tidak mendapat perhatian lebih

\footnotetext{
2000), 182.

${ }^{19}$ Abu Ja'far al-Ṭabarī, Jāmi' al-Bayān fi Ta'wīl Āy al-Qur'ān, vol. 2 (Beirut: Muassasah Al-Risālah,

${ }^{20}$ Husain al-Dzahabi, Al-Tafsīr wa al-Mufassirūn, (Kairo: Maktabah Wahbah, 2000), 149.
} 
lanjut pada tahapan berikutnya. Padahal dari sekian definisi muhkām-mutasyābih di atas, sebenarnya tampak begitu jelas bahwa konsep muhkām-mutasyābih tidak bisa dilepaskan dari pembahasan-pembahasan lain baik dalam lingkup 'ulūm al-Qur'an sendiri mapun dalam disiplin ilmu lain.

Lebih lanjut, diskursus muhkām-mutasyābih pada akhirnya mengalami proses pergeseran makna yang tidak semestinya. Pergeseran makna tersebut diantaranya adalah spesialisasi. Spesialisasi makna adalah suatu perubahan yang mengakibatkan sebuah kata menjadi memiliki makna yang lebih sempit daripada makna asli yang dimiliki. ${ }^{21}$ Makna dan definisi muhkām-mutasyābih yang begitu luas pada akhirnya sering dan hanya difahami dengan ayat-ayat teologis semata.

Pada dasarnya, teks al-Qur'an memang terbuka untuk memunculkan ikhtilāf dalam penafsiran. Oleh karena itu, perdedaan interpretasi terhadap nash agama baik berupa alQur'an maupun hadits adalah suatu hal yang sangat wajar terjadi bahkan sejak masa salaf. Salah satu kaidah utama dalam menghadapi perbedaan penafsiran dari kalangan salaf $\operatorname{adalah}^{22}$ :

$$
\text { غالب ما نقل عن السلف من الإختلاف في التفسير فهو من باب التنوع }
$$

"Pada umumnya, riwayat yang dikutip dari generasi salaf yang berupa perbedaan

$$
\text { penafsiran adalah salah satu bentuk tanawwu,", }
$$

Tanawwu' berarti ragam yang bermacam-macam namun tidak menyebabkan kontradiksi (tadlād). Penghargaan terhadap produk ijtihad generasi klasik ini memang menjadi salah satu identitas utama tradisionalis yang cenderung tekstual dalam menginterpretasikan teksteks agama. ${ }^{23}$ Kendati demikian, pada akhirnya kontradiksi (tadlād) tidak dapat terelakkan juga pada perbedaan yang diyakini sebagai tanawwu' itu. Oleh karena itu, para cendikiawan muslim meletakkan beberapa kaidah dalam menyikapi perbedaan interpretasi al-Qur'an. Jika ada perbedaan penafsiran dari kalangan mufassir, maka beberapa kaidah untuk menyikapinya. ${ }^{24}$ :

${ }^{21}$ Yunita Nugraheni, "Perubahan Makna Pada Istilah Ekonomi," MAJALAH EKONOMI DAN BISNIS 2, no. 2 (2006): 8.

${ }^{22}$ Khālid al-Sabt, Qawā'id al-Tafsīr: Jam'an wa Dirāsatan (Kairo: Dār Ibn 'Affān, t.t.), 208.

${ }^{23}$ Nicolaus Teguh Budi Harjanto, Islam and Liberalism in Contemporary Indonesia: The Political Ideas of Jaringan Islam Liberal (The Liberal Islam Network) (Ohio: The College of Arts and Sciences of Ohio University, 2003), 43.

${ }^{24}$ Husain bin Ali al-Harbī, Mukhtașar Qawā'id al-Tarjīh `inda al-Mufassirīn Dār (Kairo: Dār Ibn alJawzi, 2006), 14. 
Pertama, Jika perbedaan interpretasi yang ada masih memungkinkan untuk dikompromikan serta layak untuk dijadikan makna al-Qur'an semua maka tindakan yang diambil adalah mengkompromikan antara pendapat-pendapat yang ada (al-jam') atau menempatkan setiap penafsiran sesuai dengan konteksnya, apalagi jika masing-masing penafsiran tersebut berlandaskan kepada riwayat atau argumen yang șahīh dari al-Qur'an misalnya perbedaan ulama dalam menafsirkan QS. Al-An'an [6]: 3 berikut:

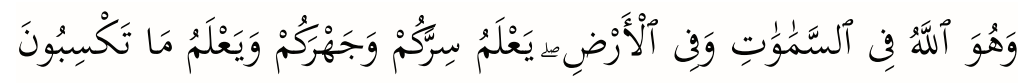

Dan Dia lah Allah di langit dan di bumi. Tidak ada sesuatu pun yang luput dari pengetahuan-Nya. Dia mengetahui semua niat, ucapan, dan perbuatan yang kalian sembunyikan maupun yang kalian nyatakan. Dan Dia akan memberi kalian balasan yang setimpal dengannya. (QS. Al-An'ām [6]: 3)

Al-Syinqīṭī menuturkan bahwa setidaknya terdapat tiga perbedaan penafsiran ulama terhadap ayat ini. Penafsiran pertama menyatakan bahwa makna "Dan Dia lah Allah di langit dan di bumi" adalah Ia satu-satunya tuhan yang berhak disembah baik di langit maupun di bumi. Penafsiran kedua menyatakan bahwa ungkapan di langit dan di bumi itu berkaitan dengan pengetahuan Allah yang berada di penggalan setelahnya, sedangkan penafsiran ketiga menyatakan bahwa ungkapan tersebut di-waqf pada kalimat al-samāwāt sehingga menunjukkan istiwā'-Nya di langit. ${ }^{25}$ Perbedaan penafsiran semacam ini bukan wilayah tarjīh karena semua maknanya layak dan bisa dipakai untuk ayat tersebut. ${ }^{26}$

Kedua, Jika terdapat perbedaan interpretasi kemudian terjadi kontradiksi antara penafsiran satu dengan penafsiran lain, tetapi sebenarnya penafsiran-penafsiran yang ada itu sama-sama memungkinkan dianggap sebagai makna ayat namun tidak memungkinkan jika membawa pemahaman suatu ayat kepada semua riwayat penafsiran yang ada itu secara bersamaan, maka tindakan yang perlu diambil adalah memilih salah satu dari penafsiran yang ada itu. Sebagai contoh dari jenis kedua ini adalah ayat-ayat yang bersifat musytarak. Lafadz musytarak adalah lafadz yang yang memiliki dua makna atau lebih dan makna-makna tersebut sama-sama kuat. ${ }^{27}$ Argumentasi wajibnya menggunakan salah satu

${ }^{25}$ Muhammad Amīn al-Syinqīițī, Adlwā' al-Bayān fì Idlāh al-Qur'ān bi al-Qur'ān (Beirut: Dār alFikr, 1995), 471.

${ }^{26}$ Muhammad Afifudin Dimyati, 'Ulūm al-Tafš̄r; Ușūluhu wa Manāhijuh (Sidoarjo: Lisan Arabi, 2016), 236.

27 Muhammad `abd al-Mun'īm al-Qi'i, Al-Așlān fì 'Ulūm al-Qur'ān, 1996, 359. Meskipun tidak semua lafadz musytarak dapat diklasifikasikan ke dalam jenis ikhtilāf ke dua dalam penafsiran ini karena ada jenis lafadz musytarak yang tidak meniscayakan kontradiksi antara makna satu 
dari makna yang ada untuk perbedaan jenis kedua ini,-- termasuk pada lafadz musytarak adalah karena apabila makna-makna tersebut dipakai semua akan menyebabkan kekacauan pada tataran konsep dan aplikasinya. ${ }^{28}$ Salah satu contoh perbedaan interpretasi jenis ke dua ini adalah penafsiran lafadz qurū' pada firman Allah SWT:

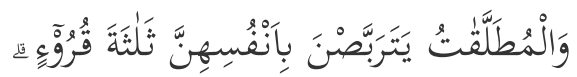

Dan para istri yang diceraikan (wajib) menahan diri mereka (menunggu) tiga kali quru'. (QS. Al-Baqarah: 228)

Para ulama berbeda pendapat dalam menafsirkan kata qurū' di ayat tersebut. AlSyāfi'’̄ menafsirkan kata qurū' sebagai masa suci sedangkan Abu Hanīfah menafsirkannya sebagai masa haidl. ${ }^{29}$ Kedua makna tersebut memang sama-sama sah untuk dijadikan sebagai makna kata qurū', namun akan kacau jika keduanya diambil secara bersamaan. Oleh karena itu, dalam memahami dan menerapkan ayat tersebut, seorang pembaca harus memilih salah satu dari maka yang ia anggap lebih kuat dengan demikian penghitungannya disesuaikan dengan penafsiran yang ia pilih. ${ }^{30}$ Berbeda dengan apabila ia memilih kedua makna sekaligus maka tentu masa iddah akan lebih lama satu periode haidl atau masa suci. Awalnya ia harus menghitung tiga masa suci atau tiga masa haidl saja tetapi jika menggunakan kedua makna sekaligus maka ia jadi menghitung tiga masa suci dan masa haidl.

Ketiga, Jika ada perbedaan penafsiran yang menyimpang atau berbeda dengan alQur'an, Sunnah dan Ijmā' maka penafsiran yang menyelisihi ketiga sumber paling otoritatif tersebut harus ditolak dan dikesampingkan. Salah satu contoh perbedaan jenis ketiga ini misalnya riwayat penafsiran yang disandarkan kepada Sa'id bin Musayyab.

dengan makna lain. Abd al-Karim al-Namlah mengklasifikasikan musytarak menjadi tujuh jenis sedangkan musytarak yang ada dalam uraian jenis kedua pada kaidah tarjīh ini dimaksudkan pada lafadz musytarak jenis pertama Abd al-Karīm al-Namlah. Adapun pada jenis musytarak yang tidak bertentangan maka ulama berbeda pendapat apakah makna-makna yang berbeda itu sama-sama bisa dipasangkan kepada teks yang bersangkutan. Abd al-Karīm al-Namlah, Al-Muhadzdzab fì 'Ilm Ușul al-Fiqh al-Muqāran (Riyadh: Maktabah Al-Ruysd, 1999), 1097.

${ }_{28}^{28}$ Khalāf, Ilmū Ușūl al-Fiqh wa Khulāṣah Tārīkh al-Tasyrì', 170.

${ }^{29}$ Hasan bin Muhammad al-`Aț̣ār, Häsyiyah al- 'Atțār 'alā Syarh Jalāl al-Dīn al-Mahalli 'alā Jam ${ }^{i}$ al-Jawāmi, ’ vol. 2 (Beirut: Dār al-Kutub al-Ilmiyah, t.t.), 95.

${ }^{30}$ Syafi'i membolehkan pemaknaan lafadz musytarak dengan lebih dari satu makna dengan syarat tidak ada qarinah atau faktor pendukung yang mengharuskan ia dimaknai dengan salah satu maknanya saja. Namun dalam konteks rangkaian ayat tentunya terdapat qarinah yang membersamai lafadz tersebut sehingga Syafi'i pun pasti mengambil keputusan salah satu dari makna-makna yang ada seperti yang ia tempuh saat beristidlāl pada kata qurū' . 'Alā’ al-Dīn al-Bukhārī, Kasyf al-Asrār Syarh Usūul al-Bazdawī. (Beirut: Dār alKitāb al-Islāmi, t.t.), 40. 
Riwayat tersebut menjelaskan bahwa yang dimaksud "buah dari pohon khuldi" yang ada di kisah-kisah dikeluarkannya Adam dan Hawa di Surga bukanlah Adam yang makan langsung dari pohon khuldi,- karena sesuai dengan keyakinan ahlussunnah bahwa seorang nabi tidak akan melakukan suatu dosa atau melanggar tuhannya. Kemudian ia menakwil bahwa Hawa terlebih dahulu memberikan minum khamr kepada Adam sehingga saat ia mabuk maka ia memberikan buah khuldi itu kepada Adam lalu ia pun memakannya. Terlepas dari validitas Riwayat di atas, penafsiran yang disandarkan kepada Sa'id bin Musayyab ini mesti ditolak karena ia menyelisihi ayat lain yang menyatakan bahwa Khamr yang ada di Surga itu tidaklah menyebabkan mabuk (QS. Al-Șāffāt 47). ${ }^{31}$

Keempat, Jika ada sekian perbedaan penafsiran ulama namun perbedaan-perbedaan yang ada tersebut tidak menyelisihi al-Qur'an, sunnah dan juga ijmā', serta tidak saling berlawanan (kontradiksi) namun juga tidak dapat dikompromikan sehingga meniscayakan pembaca untuk mendahulukan salah satu dari penafsiran tersebut. Pada kasus semacam inilah dibutuhkan serangkaian kaidah tarjīh dan argument untuk memilih penafsiran mana yang harus didahulukan. ${ }^{32}$

Dalam menyikapi perbedaan 'Ulāma'mengenai interpretasi QS. Ali Imrān [3]:7 serta konsep muhkam-mutsyaābih di dalamnya, perlu diperjelas posisi ikhtilāf tafsīr yang terjadi di ayat ini termasuk jenis perbedaan yang mana. Penentuan posisi ini penting agar sikap yang tepat dalam menghadapi perbedaan tersebut dapat diambil dengan tepat. Jika dianggap menyimpang dari al-Qur'an dan Sunnah karena ada beberapa definisi yang menyatakan bahwa ayat-ayat mutasyābihāt bisa ditakwil maka hal ini dapat dibantah dengan fakta-fakta sejumlah riwayat takwil yang dilakukan oleh para ulama bahkan dari kalangan sahabat terhadap ayat-ayat yang mutasyābihāt. Terdapat banyak Riwayat yang menjelaskan tafsir ayat-ayat yang dinilai mutasyābihāt di literatur tafsīr bi al-ma'tsūr baik terkait ayat teologi, fawātih al-suwar maupun ayat-ayat mutasyābihāt lainnya.

Jika dinilai sebagai ikhtilāf yang disebabkan karena lafadz muhkam-mutasyābih adalah lafadz yang musytarak (memiliki makna lebih dari satu dan sama-sama kuat) maka musyārakah makna ini sudah diselesaikan dengan konsep tasyabuh 'ām dan khāṣ yang diajukan para ulama. Tasyābuh 'ām adalah konsep tasyābuh yang menjelaskan bahwa seluruh al-Qur'an bersifat mutasyābih, artinya semuanya bersifat sama dan berdekatan dalam kefashihan dan keindahan bahasanya. Dengan demikian semua ayat al-Qur'an

\footnotetext{
31 al-Harbī, Mukhtașar Qawā'id al-Tarjīh `inda al-Mufassirīn Dār, 17.

${ }^{32}$ Dimyati, 'Ulūm al-Tafsīr; Ușūluhu wa Manāhijuh, 237.
} 
berkarakter mutasyābih sesuai dengan QS.al-Zumar [39]: 23. Adapun ihkām/muhkam `ām adalah konsep bahwa seluruh ayat al-Qur'an bersifat kokoh, sempurna dan tidak bertantangan antara ayat-ayatnya sesuai dengan QS. Hud [11]: 1. ${ }^{33}$ Dengan demikian, muhkam-mutasyābih yang ada di QS. Ali Imran [3]: 7 dan penafsiran-penafsiran yang ada tidak dapat diberlakukan sebagai jenis perbedaan yang musytarak sebagaimana klasifikasi ke dua.

Kemungkinan yang tersisa adalah jenis perbedaan yang pertama atau yang terakhir, artinya apakah perbedaan definisi dan interpretasi terhadap muhkam-mutasyābih di QS. Ali Imran [3]: 7 itu masih bisa dikompromikan sesuai dengan tempat masing-masing atau harus ditarjih karena proses al-jam ` tidak lagi memungkinkan. Jika perbedaan interpretasi muhkam-mutasyābih dianggap sebagai perbedaan yang harsu di-tarjih maka tentunya para ulama akan menjelaskan pendapat mana yang rājih berikut alasan kenapa definisi dan interpretasi tersebut dinilai lebih räjih. Realitanya perbedaan tentang penafsiran muhkammutasyābih ini tidak diakhiri dengan komentar para cendikiawan tentang pendapat yang rājih dan marjūh. Bukti lain bahwa tarjīh bukanlah sikap yang ditempuh ulama dalam menghadapi perbedaan ini adalah pemberlakuan konsep muhkam-mutasyābih tidak hanya pada bingkai teologis yang dinilai "tidak tersentuh manusia" tetapi juga banyak diberlakukan dalam beberapa literatur fiqh klasik.

Dengan berbagai asumsi di atas, maka pembatasan makna muhkam-mutasyābih adalah suatu bentuk penyempitan makna (spesialisasi) yang mestinya tidak dilakukan seorang mufassir. Konsep muhkam-mutasyābih mestinya diberlakukan, dielaborasi dan dikembangkan sebagaimana konsep-konsep lain dalam 'ulūm al-Qur'ān seperti sabab nuzūl, munāsabah, 'ām-khāṣ dan lain-lain dalam rangka memperoleh interpretasi yang lebih holistik. Apalagi jika definisi muhkām-mutasyābih yang dipakai adalah definisi yang lebih kompleks karena melibatkan beberapa konsep lain seperti nāsikh-mansūkh, zāhir-nās dan lain-lain maka resitasi al-Qur'an dalam bingkai muhkām-mutasyābih akan memperoleh makna yang lebih luas dan bisa jadi lebih kontekstual.

Adapun fenomena spesialisasi makna pada pembahasan bab muhkam-mutasyābih dalam 'ulūm al-Qur'ān sebenarnya sangat disayangkan. Sebagai contoh misalnya dalam al-Burhān fì 'Ulūm al-Qur'ān, salah satu karya terlengkap sampai abad ke delapan Hijriyah dalam disiplin 'Ulūm al-Qur'ān. Setelah membahas teorisasi muhkam-mutasyābih

\footnotetext{
${ }^{33}$ Muhammad Anwar Firdausi, "Membincang Ayat-ayat Muhkam dan Mutasyabih," Ulul Albab Jurnal Studi Islam 16, no. 1 (2015): 82.
} 
sebagai bab ke 36, al-Zarkasyī melanjutkan bab ke 37 dengan judul bab F̄̄ Hukm al-Āyāt al-Mutasyābihāt al-Waridah fì al-Ṣifāt (Hukum ayat-ayat Mutasyābihāt dalam Ayat-Ayat Sifat Allah SWT). ${ }^{34}$ Demikian pula al-Suyūṭi dalam al-Itqān fì 'Ulūm al-Qur'ān. Walaupun tidak dijadikan bab tersendiri, pembahasan ayat-ayat sifat sebagai ayat mutasyābih juga dibahas panjang lebar oleh al-Suyūṭ̄ sebagai subbab dalam muhkammutasyābih. Anehnya subbab tersebut justru lebih panjang daripada konten bab utama yang mengelaborasi teori umum muhkam-mutasyābih. ${ }^{35}$ Sebagai model dalam disiplin ‘utūm al-Qur'ān, tentu kedua karya tersebut berdampak pada litertur-literatur setelahnya baik dari segi konten maupun sistematika. Beberapa kitab 'ulūm al-Qur'ān model-model al-Itqān dan al-Burhān yang menghimpun berbagai bab dalam disiplin 'ulūm al-Qur'ān pun akhirnya juga banyak melakukan spesialisasi-spesialisasi ini misalnya Al-Mabāhits fī 'Ulūm al-Qur'ān karya Șubḥi al-Șālih ${ }^{36}$ dan Dirāsāt fì 'Ulūm al-Qur'ān karya Muhammad Bakr Ismail ${ }^{37}$.

\section{Diskursus Muhkām-Mutasyābih dalam Yurisprudensi Islam}

Spesialisasi makna yang terjadi pada konsep muhkam-mutasyābih menyebabkan persepsi di kalangan umat Islam bahkan cendikiawan muslim bahwa muhkām-mutasyābih sangat identik dengan ayat teologis. Padahal pada dasarnya, dari sekian definisi muhkāmmutasyābih yang diinventarisasi para ulama, beberapa definisi sama sekali tidak terlepas dari konteks ahkām. Dari definisi yang diajukan al-Suyūṭ̄ saja, enam dari tiga belas definisi yang ia cantumkan di bab muhkām-mutasyābih, sangat menggambarkan nuansa ahkām. Kelima definisi tersebut adalah:

a. Muhkam : Terdiri dari kewajiban-kewajiban, Janji dan ancaman Mutasyābih : Terdiri dari kisah-kisah dan perumpamaan

Definisi ini meskipun tidak membaca muhkām-mutasyābih dalam bingkai ahkām secara keseluruhan, namun memasukkan unsur "kewajiban" dalam definisi muhkam tidak dapat dilepaskan dari konsekuensi legal. Hal-hal yang berkaitan dengan ahkām dalam Islam tentu menjadi bagian dari pembahasan ahkām.

b. Muhkām : Sesuatu yang tidak dinasakh Mutasyābih : Sesuatu yang telah dinasakh

\footnotetext{
${ }^{34}$ al-Zarkasȳ̄, al-Burhān fì 'Ulūm al-Qur'ān, 68.

35 al-Suyūṭī, Al-Itqān fì 'Ulūm al-Qur'ān, 315.

${ }^{36}$ Șubḥi al-Ṣālih, Al-Mabāhits fì 'Ulūm al-Qur'ān (Beirut: Dār al-Ilm li al-Malāyīn, 2000), 284.

${ }^{37}$ Muhammad Bakr Ismail, Dirāsāt fì 'Ulūm al-Qur'ān (Kairo: Dār al-Manār, t.t.), 90.
} 
c. Muhkām : Sesuatu yang menjelaskan halal-haram

Mutasyābih : Segala yang membahas selain halal-haram

d. Muhkām : Perintah dan larangan

Mutasyābih : Permulaan beberapa surat (Fawātih al-Suwar)

e. Muhkām : Sesuatu yang harus diamalkan

Mutasyābih : Sesuatu yang cukup diimani tanpa harus diamalkan

f. Muhkām : Nāsikh, Halal-haram, batasan-batasan, kewajiban-kewajiban serta hal yang tidak cukup diimani tapi juga harus diamalkan.

Mutasyābih : Mansūkh, Muqaddam-muakhkhar, amtsāl, aqsām, dan segala sesuatu yang cukup diimani saja tanpa perlu diamalkan

Pada bagian definisi-definisi ini, nuansa ahkām lebih kentara dibandingkan dengan definisi sebelumnya. Halal-haram, kewajiban dan larangan merupakan wilayah dari ahkām al- 'amaliyah (fiqh). Selain memasukkan halal-haram, ia juga menyentuh konsep uṣüliyah berupa naskh. Pembahasan naskh tentu tidak mungkin dibaca melalui bingkai selain ahkām karena definisi dari naskh sendiri adalah menghapus suatu hukum syara' dengan hukum syara' yang lain setelahnya. ${ }^{38}$ Naskh hanya diberlakukan pada teks-teks agama yang bersifat perintah atau larangan bukan pada teks yang bersifat berita. Perintah dan larangan dalam pemetaan kandungan al-Qur'an dan Sunnah tentu merupakan wilayah ahkām ‘amāliyyah (Fiqh). Adapun teks yang berisi berita atau keyakinan tidak bisa diberlakukan naskh. ${ }^{39}$ Definisi-definisi ini meneguhkan bahwa konsep muhkam-mutasyābih tidak hanya berkaitan dengan ayat-ayat teologis saja tetapi juga sangat berkaitan dengan ayat-ayat hukum.

Tidak hanya berhenti pada ranah definisi, konsep muhkam-mutasyābih juga mendapatkan perhatian secara teoritis dari para ulama dalam bingkai yurisprudensi Islam. Al-Ṭībi menyatakan bahwa lafadz itu adakalanya memang hanya memiliki satu makna dan adakalanya memungkinkan memiliki makna lebih dari satu. Lafadz yang jelas-jelas hanya memiliki satu makna disebut naṣ, sedangkan lafadz yang bermakna lebih dari satu dibagi menjadi dua. Pertama, Apabila makna utama lafadz tersebut lebih kuat dari makna lain maka lafadz itu disebut $z \bar{a} h i r$. Kedua, Jika makna asli dari lafadz tersebut tidak lebih kuat daripada makna utamanya maka terbagi lagi menjadi dua. Apabila makna-makna tersebut

\footnotetext{
${ }^{38}$ Qatādah, Al-Nāsikh wa al-Mansūkh (Beirut: Muassasah al-Risālah, 6), 6.

39 Ibn al-Jawzi, Al-Mușaffa bi Akaffi Ahl al-Rusūkh min 'Ilm al-Nāsikh wa al-Mansūkh (Beirut: Muassasah Al-Risālah, 1998), 12.
} 
setara dengan makna aslinya maka disebut mujmal, sedangkan apabila makna-makna tersebut tidak setara (lebih kuat) maka disebut sebagai mu'awwal. Lafadz yang berpotensi untuk dinilai sebagai naṣ dan zăhir disebut muhkam, sedangkan lafadz yang beririsan antara mujmal dan mu'awwal disebut mutasyābih. ${ }^{40}$

Selain dikembangkan dalam ranah konseptual seperti $A l$-Ṭ̂̄bī, ternyata konsep muhkam-mutasyābih juga dikembangkan dalam langkah praktis interpretasi al-Qur'an yang berbasis ahkām. Al-Ṭaḥāwī (w.321 H) adalah salah satu contoh ulama yang banyak menggunakan konsep muhkām-mutasyābih secara eksplisit saat menafsirkan ayat-ayat $a h k \bar{a} m .{ }^{41}$ Misalnya saat menafsirkan firman Allah SWT:

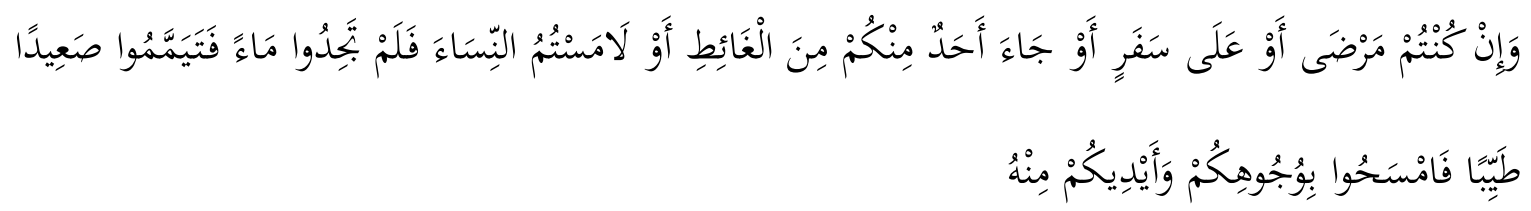

"Dan jika kamu sakit atau dalam perjalanan atau kembali dari tempat buang air (kakus) atau menyentuh perempuan, lalu kamu tidak memperoleh air, maka bertayammumlah dengan tanah yang baik (bersih); usaplah mukamu dan tanganmu dengan tanah itu." (QS. Al-Mā'idah [5]: 6)

Al-Ṭahāwì berkomentar bahwa kalimat famsaḥu bi wujūhikum termasuk ungkapan muhkam yang dapat berdiri sendiri. Berbeda dengan wa aydīkum minhu. Menurutnya ungkapan wa aydīkum minhu termasuk ungkapan mutasyābih yang diselisihkan para ulama tentang tafsirnya. Setelah itu, ia menguraikan perbedaan sejumlah madzhab fikih dalam memahami dan meng istinbāt hukum dari ungkapan wa aydīkum minhu itu ${ }^{42}$. Al-Ṭahāwwi melibatkan konsep muhkam-mutasyābih tidak hanya pada saat menafsirkan ayat itu saja, tetapi juga mengelaborasinya saat menafsirkan ayat-ayat ahkam lain seperti saat menafsirkan tentang teknis pemberian makan orang miskin sebagai kaffārat (penebus kesalahan) bagi orang yang melakukan zihār kepada istrinya di QS. Al-Mujādilah [58] 4.

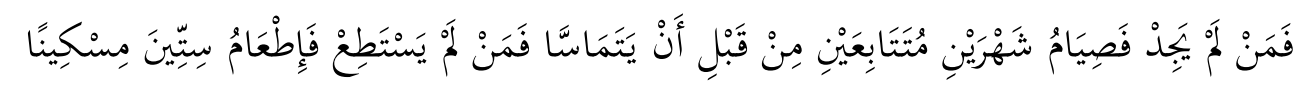
Barangsiapa yang tidak mendapatkan (budak), maka (wajib atasnya) berpuasa dua bulan berturut-turut sebelum keduanya bercampur. Maka siapa yang tidak kuasa (wajiblah atasnya) memberi makan enam puluh orang miskin. (QS. Al-Mujādilah [58]: 4)

${ }^{40}$ al-Suyūụ̂i, Al-Itqān fì 'Ulüm al-Qur'ān, 318.

${ }^{41}$ Abu Ja'far Al-Ṭahạ̄wī, Ahkām al-Qur'ān al-Karīm (Istanbul: Markaz al-Buḥūts al-Islāmiyyah alTībi; li Waqf al-Diyānah al-Turkī, 1998), 102.

${ }^{42}$ Al-Ṭahāwīi, 103. 
Menurut Al-Tahāwī, perintah memberi makan orang miskin untuk suami yang melakukan $z i h \bar{a} r^{43}$ kepada istrinya berikut jumlah orang miskinnya termasuk perintah yang muhkam, sedangkan jumlah makanan yang diberikan berikut golongan yang berhak menerima makanan tersebut termasuk bagian dari al-Qur'an yang mutasyābih. ${ }^{44}$

Bukan hanya Al-Ṭhạāwì, beberapa ulama lain juga melibatkan konsep ini dalam proses interpertasi secara eksplisit seperti al-Jașsāṣ (w. $370 \mathrm{H})^{45}$ dan al-Zuhaylī (w. 1437 H) ${ }^{46}$ Adapun secara implisit, tentu bukan hanya ketiga ulama itu yang mengelaborasi konsep muhkām-mutasyābih dalam proses interpretasi al-Qur'an namun mereka tidak menampakkan proses itu dalam sebuah tulisan sehingga tidak terbaca secara langsung oleh para pembaca.

\section{Prinsip Pengembangan Konsep Muhkām-Mutasyābih dalam Tafsir Kontekstual}

Al-Qur'an memang telah final teksnya sejak terputusnya wahyu dengan meninggalnya Rasulullah SAW, namun proses pemahaman, interpretasi dan penggalian nilai-nilai al-Qur'an yang universal adalah sebuah pekerjaan yang terus-menerus dan tidak ada hentinya. Hal ini terbukti dengan semakin luasnya tafsir di masa sahabat dibanding pada masa Rasulullah sendiri. Demikian pula pada generasi-generasi setelahnya tentu tafsir semakin berkembang seiring dengan permasalahan yang perlu dijawab oleh al-Qur'an. Bukan hanya produk penafsiran, metode penafsiran pun juga mengalami perkembangan. Pada masa sahabat, narasi-narasi tentang konsep-konsep dasar dalam llmu tafsir dan alQur'an seperti naskh, ta'wīl, 'ām-khāṣ dan lain-lain tentu sudah ada, namun teorisasi yang tersistematiskan justru baru ada pada generasi-generasi setelahnya. Perkembanganperkembangan itu terkadang menjadi dinamis di suatu masa, namun terkadang juga menjadi statis bahkan menurun di masa yang lain.

Konsep muhkam-mutasyābih sebagai bagian dari 'ulūm al-Qur'ān pun tentu juga demikian. Pembangunan narasi, teorisasi bahkan perdebatan para cendikiawan dari berbagai aliran telah direkam dalam catatan sejarah ilmu al-Qur'an. Namun fakta yang didapat ternyata spesialisasi makna terjadi secara masal dalam konsep muhkām-

${ }^{43}$ Zihār adalah menyamakan istri dengan ibu dan bertujuan untuk mengharamkannya dari hakhaknya sebagai istri. Ibnu Hajar al-Haitsami, Tuhfah al-Muhtāj Syarh al-Minhāj, vol. 8 (Mesir: al-Maktabah al-Tijāriyah al-Kubrā, 1983), 178.

${ }^{44} \mathrm{Al}$-Ṭahāāì, Ahkām al-Qur'ān al-Karīm, 402.

${ }^{45}$ al-Jașșāṣ, Ahkām al-Qur'ān (Beirut: Dār Ihyā' al-Turātas al-`Arabī, 2000), 191.

${ }^{46}$ Wahbah Muștafāa al-Zuhayli, Al-Tafsìr al-Munìr fì al-Aqìdah wa al-Syarī'ah wa al-Manhaj (Beirut: Dār al-Fikr al-Mu'āṣir, 1998), 155. 
mutasyābih. Hal ini dibuktikan dengan minimnya diskursus dan elaborasi konsep muhkammutasyābih dalam proses interpretasi al-Qur'an. Dari seratus literatur tafsir yang ada di program al-Maktabah al-Syāmilah, pelacakan kata muhkam-mutasyābih pada selain pembahasan QS. Ali Imran [3]: 7 dan QS. Al-Nahl [16]: 1 tidak ditemukan kecuali pada tafsir al-Ṭahāwī, al-Jașṣās, dan al-Munīr.

Spesialisasi yang terjadi di literatur 'ulūm al-Qur'ān sebenarnya bisa di-reframing. Sikap yang ditempuh ulama terdahulu tidaklah menunjukkan sebagai suatu hal yang final bagi pengembangan konsep muhkam-mutasyābih tetapi harus dipandang sebagai sebuah tantangan bagi generasi setelahnya untuk mengembangkan dan menerapkan konsep itu dalam interpretasi al-Qur'an. Namun sayangnya sikap pertama justru lebih terlihat dalam panggung sejarah ilmu al-Qur'an. Untuk itu upaya reinventarisasi konsep muhkammutasyābih perlu dipertimbangkan dalam rangka mengembangkan interpretasi al-Qur'an yang harus disesuaikan dengan tuntunan ruang dan waktu.

Beberapa prinsip yang perlu dipertimbangkan dalam rangka upaya reinventing konsep muhkam-mutasyābih dalam interpretasi al-Qur'an kontekstual adalah:

1. Menghindari spesialisasi makna muhkam-mutasyābih pada ayat-ayat sifat

Pembahasan ayat-ayat sifat dengan perdebatan muhkam-mutasyābih sudah begitu marak dilakukan ulama terdahulu terutama para pakar ilmu kalam. Diskursus muhkam-mutasyābih tentang teologi tidak terlalu berbeda secara signifikan. Jika ada pendapat-pendapat baru pun, sandaran kepada golongan atau aliran tertentu di masa dahulu bisa dilacak dengan tidak begitu sulit, sehingga sudah saatnya diskursus muhkam-mutasyābih dielaborasi lebih lanjut dalam bidang lain selain teologi. Salah satu yang sangat penting adalah dalam rangka-rangka interpretasi ayat ahkām yang selalu menjadi sumber utama umat Islam di berbagai zaman dalam rangka menjawab kebutuhan mereka.

2. Menimbang ulang pemilihan makna muhkam-mutasyābih sesuai dengan ayat yang ditafsirkan

Setelah spesialisasi dikesampingkan, proses interventarisasi konsep muhkammutasyābih perlu dilakukan agar definisi dan konsep yang dipakai bisa sesuai dengan konteks ayat atau permasalahan yang sedang dipecahkan. Klasifikasi muhkammutasyābih yang dilakukan oleh al-Rāghib al-Așfihani bisa menjadi salah satu titik 
tolak awal dalam membedakan sikap yang harus diambil saat berinteraksi dengan muhkam-mutasyābih.

Al-Raghib al-Aṣfihāni mendefinisikan muhkam sebagai sesuatu yang disepakati tafsirnya, sedangkan mutasyābih adalah sesuatu yang diperselisihkan tafsirnya. ${ }^{47}$ Definisi ini lah yang lantas dipakai oleh para mufassir yang mengelaborasi muhkam-mutasyābih secara eksplisit dalam penafsirannya seperti al-Ṭaḥāwī, al-Jașșās, dan al-Zuhaylī. Bagi al-Așfihāni, mutasyābih dibagi lagi menjadi tiga jenis berdasarkan sikap yang harus ditempuh seseorang dalam berinteraksi dengannya. Pertama, mutasyābih yang tidak mungkin sama sekali diketahui maknanya oleh siapapun dan kapanpun seperti waktu terjadinya hari kiamat, keluarnya Dajjāl dan halhal gahib sejenisnya. Kedua, mutasyābih yang dapat diketahui takwilnya oleh manusia seperti lafadz-lafadz yang jarang dipakai dan diketahui serta hukum-hukum detil yang perlu diistinbat. Ketiga, mutasyābih yang potensinya untuk diketahui manusia masih diragukan atau diperdebatkan. Jika diklasifikasikan sedemikian rupa, maka seseorang dapat memilih berhenti di salah satu dari dua tempat waqf (illa Allah atau wa alRasikhūna fi al-Ilm) saat membaca QS. Ali Imrān [3]: 7:

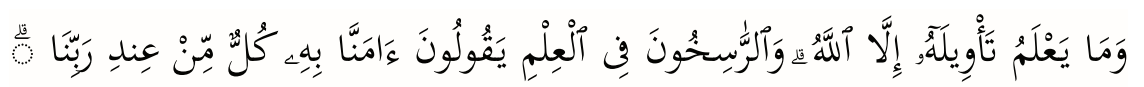

"Dan tidak ada yang mengetahui ta'wilnya melainkan Allah dan orang-orang yang mendalam ilmunya berkata: "Kami beriman kepada ayat-ayat yang mutasyaabihaat, semuanya itu dari sisi Tuhan kami" (QS. Ali Imrān [3]: 7)

Jika definisi muhkam-mutasyābih sebenarnya telah banyak opsinya sejak masa klasik, maka sebenarnya para cendikiawan ataupun mufassirin berhak menentukan definisi dan konsep mana yang mereka pakai. Bahkan menyusun ulang konsep muhkam-mutasyābih bukanlah suatu hal yang terlarang dalam pengembangan ilmu alQur'an karena pada realitanya, konsep muhkam-mutasyābih yang telah ada juga bukan merupakan suatu konsensus ( $\left(j m \bar{a}^{\prime}\right.$ ) yang bisa dianggap final. Sejauh ini, belum ada literatur valid yang menyebutkan riwayat bahwa ada konsensus ulama dalam memformulasikan konsep muhkam-mutasyābih ataupun sikap yang harus diambil seseorang dalam berinteraksi dengan muhkam-mutasyābih. Hal ini menunjukkan

${ }^{47}$ Al-Raghib al-Aṣfihāni, Al-Mufradāt fì Gharīb al-Qur'ān (Beirut: Dār al-Qalam, 1992), 443. 
bahwa pemilihan, perumusan dan pengembangan konsep muhkam-mutasyābih masih sangat terbuka dalam rangka pengembangan ilmu al-Qur'an dan Tafsir.

3. Reframing konsep muhkam-mutasyābih dalam proses interpretasi al-Qur'an kontekstual sesuai dengan maqāṣid al-syarīa ah

Maqāșid al-syarīa didefinisikan oleh Ṭāhir bin 'āsyur sebagai prinsip-prinsip dan hikmah-hikmah yang senantiasa diperhatikan dan dipergunakan oleh Allah sebagai pemegang otoritas syariat dalam menetapkan semua atau sebagian besar hukum syariat untuk makhluknya. Adapun al-Fāsī mendefinisikan maqāṣsid alsyarīah sebagai Maksud dan Tujuan yang hendak dicapai syariat dalam menetapkan hukum dan ketetapannya,- demi mencapai kemaslahatan manusia. ${ }^{48}$ Maqāṣid alSyarī'ah adalah upaya para perumusnya terutama dari kalangan $u s ̣ u \bar{l} l \overline{~ u n t u k}$ menjawab dan mengurai pertanyaan mendasar "Apa tujuan dan maksud Allah dengan wahyu dan alam raya ciptaanNya ini?". 49

Al-Qur'an sebagai sumber primer paling utama dari syariat Islam tentu juga menjadi sumber utama para ulama dalam menggagas maqāsịid al-syarì'ah. Dengan demikian wacana tafsir al-Qur'an dengan memberikan atensi khusus terhadap maqāṣìd al-syarī'ah atau yang sering disebut sebagai tafsīr maqāșìdi bukanlah wacana baru dalam dunia tafsir al-Qur'an. Memahami maqāṣid dari suatu naṣ berarti menggali rahasia-rahasia dan mașlahah yang ada dalam teks tersebut. Faktanya, perebutan antara implementasi teks dengan sesuatu yang dinilai sebagai maṣlahah (konteks) sering kali terjadi dalam penafsiran al-Qur'an. Menghadirkan maqāṣid syarī’ah dalam tafsir diharapkan menjadi penengah antara pembacaan yang terlalu tekstual dengan pembacaan hermeneutis ${ }^{50}$ yang kemudian dinilai terlalu "lepas" dari horison teks. Proses yang demikian diharapkan dapat menawarkan penafsiran kontekstual yang tetap berkaitan erat dengan teks secara moral dan values-nya.

Prinsip maqāsid syarīah ini kemudian dapat dielaborasikan dengan konsep muhkam-mutasyābih yang masih terbuka dalam ijtihad tafsir. Pembacaan muhkammutasyābih dalam bingkai maqāsid syarīah memiliki prospek tersendiri dalam

${ }^{48}$ Nūr al-Dīn al-Khādimī, 'Ilm al-Maqāșid al-Syarī’ ah (Maktabah al- 'Abīkan, 2001), 13.

${ }^{49}$ Kusmana Kusmana, "EPISTEMOLOGI TAFSIR MAQASIDI," MUTAWATIR 6, no. 2 (7 Februari 2018): 208, https://doi.org/10.15642/mutawatir.2016.6.2.206-231.

${ }^{50}$ M. Ainur Rifqi A. Halil Thahir, "Tafsir Maqasidi; Building Interpretation Paradigm Based on Mashlahah," Millalh: Jurnal Studi Agama 18, no. 2 (2019): 344, https://doi.org/10.20885/millah.vol18.iss2.art7. 
pembacaan ayat ahkam karena masing-masing konteks dapat menentukan standard muhkām-mutasyābih sesuai dengan tuntutan mașlahah di masing-masing bidang. Maqāṣid al-Syari'ah itu tentu harus mencakup dan sesuai dengan maqāṣid al-Qur'ān baik berupa kemaslahatan pribadi, kemaslahatan sosial-lokal dan kemaslahatan universal. $^{51}$ Ayat-ayat yang tidak bertentangan dengan maqāsid syarī ah diposisikan sebagai ayat muhkam sedangkan ayat-ayat yang bertentangan dengan maqāsid syarīah dapat diposisikan sebagai mutasyābihāt. Dengan demikian proses interpretasi dan implementasi ayat-ayat mutasyābihāt mesti memerhatikan muhkamāt. Bentuk nyata pelibatan maqāṣid syarī'ah dan muhkam-mutasyābih ini dapat dilakukan dengan terlebih dahulu menentukan main values yang disusun berdasarkan prinsip maqāṣid syarīah. Main values itulah yang kemudian menjadi pegangan utama dalam proses interpretasi dan implementasi.

Sebagai contoh misalnya dalam kajian gender, terlebih dahulu seorang penafsir atau pembaca menentukan main values dalam bidang gender dengan berdasarkan maqāṣid al-syarī'ah. Main values itu kemudian dijadikan sebagai pegangan utama dalam menafsirkan ayat-ayat bias gender. Main values itu berfungsi untuk mengontrol penafsir agar tidak terlalu lepas dari syāri' dengan berpegang teguh pada ghayahNya sekaligus berfungsi untuk mengkontekstualisasikan teks.

Adapun pada selain ayat ahkām, pendekatan maqāșid syarī'ah bisa diganti dengan sesuatu yang mewakilinya di masing-masing bidang. Sebagai salah satu contoh misalnya dalam pembacaan ayat-ayat $i l m \bar{\imath}$, kebenaran universal yang telah disepakati para pakar pengetahuan dapat dijadikan sebagai pegangan dalam perumusan main values. Hal ini diharapkan dapat menampilkan wajah al-Qur'an yang ramah dengan ayat-ayat kauniyah, bukan mempertentangkan antara kebenaran ilmiah dengan teks alQur'an dan bukan juga menjadikan al-Qur'an sebagai pembenaran terhadap suatu teori ilmiah baru yang masih diperdebatkan.

Formulasi konsep muhkam-mutasyābih dalam pengembangan interpretasi alQur'an semacam ini telah ditempuh beberapa pemikir di Indonesia. Dalam bidang ahkām, Faqihuddin Abdul Kodir menjadi contoh yang representatif dengan "Qirā'ah Mubadalah"-nya. Sekalipun tidak berbicara Panjang lebar tentang muhkam-

51 Abdul Mustaqim, Argumentasi Keniscayaan Tafsir Maqashidi sebagai Basis Moderasi Islam (Yogyakarta: UIN Sunana Kalijaga, 2019). dalam Ihda Hani'atun Nisa', "Pembacaan Tafsir Maqashidi terhadap Keselamatan Agama Selain Islam dalam Al-Qur'an," ILMU USHULUDDIN 7, no. 2 (9 September 2020): 199, https://doi.org/10.15408/iu.v7i2.16774. 
mutasyābih, Kodir berani mereformulasikan muhkam-mutasyābih dalam pembacaan ayat-ayat misoginis. Baginya, ayat-ayat yang menegaskan kesalingan secara eksplisit adalah ayat-ayat muhkam. ${ }^{52}$ Sebaliknya ayat-ayat yang bias terhadap salah satu gender adalah ayat mutasyābih yang pemaknaanya harus dikembalikan ke bagian pertama.

Dalam konteks selain ayat ahkām, pemaknaan baru terhadap muhkam-mutasyābih dilakukan oleh Agus Mustofa, seorang penulis produktif dengan seri diskusi tasawuf yang seringkali bersinggungan dengat ayat-ayat al-Qur'an sebagai tema-tema utama. Gagasan muhkam-mutasyābihāt dalam metode puzzle yang ia gagas untuk memehami al-Qur'an adalah sebagai berikut: Pertama, Memilih atau menentukan definisi muhkam-mutasyābih. Ia mengartikan muhkam sebagai ayat-ayat yang jelas dan gamblang maknanya sehingga dijadikan sebagai pokok isi al-Qur'an, sedangkan mutasyābih adalah ayat-ayat yang memiliki makna lebih dalam sehingga baru bisa difahami apabila dilakukan eksplorasi mendalam terhadapnya. ${ }^{53} \mathrm{Kedua}$, Menyusun ayat-ayat mutasyābihat yang berkaitan dengan suatu tema yang ditafsirkan ${ }^{54}$ dan Ketiga, Mengembalikan pemaknaan ayat mutasyābih kepada muhkam yang jelas-jelas tidak bertentangan dengan pengetahuan dan keempat, menekankan pentingnya "niat baik" dalam memperoleh gambaran utuh tentang suatu konsep dalam al-Qur'an dan tidak menganggapnya sebagai penafsiran final. ${ }^{55}$

Dengan membuka kembali kesempatan muhkām-mutasyābih seperti langkah-langkah di atas tidak berarti menentang konsep yang disusun oleh para ulama sebelumnya karena landasan definisi, konsep dan sikap yang diambil sebenarnya telah mengacu pada hal-hal yang telah ada sejak masa klasik. Pengembangan konseptual semacam ini justru menjadi pelengkap terhadap celah akademis yang belum sempat dituntaskan oleh ulama terdahulu sekaligus menjawab tantangan dan tuntutan tafsir al-Qur'an di era kontemporer.

\section{Kesimpulan}

Konsep muhkam-mutasyābih telah mengalami dinamisasi sejak perkembangan ilmu al-Qur'an masa klasik, namun sayangnya spesialisasi makna yang terjadi pada konsep ini menyebabkan pembatasan ruang lingkup pembahasan muhkam-mutasyābih pada ayat-ayat

\footnotetext{
${ }^{52}$ Faqihuddin Abdul Kodir, Qirā'ah Mubadalah (Yogyakarta: IRCiSoD, 2019), 159.

${ }^{53}$ Agus Mustofa, "Memahami Al-Qur'an Dengan Metode Puzzle" (Surabaya: PADMA Press, 2008),

${ }^{54}$ Mustofa, 186.

${ }^{55}$ Mustofa, 226.
} 193. 
teologis saja. Proses inventarisir ulang pada konsep muhkam-mutasyābih menghasilkan kesimpulan bahwa muhkam-mutasyābih ternyata tidak hanya berkaitan dengan teologi tetapi juga berkaitan dengan ahkām dan bahkan sisi al-Qur'an lain. Hal ini bahkan ada sejak masa ulama klasik. Oleh karena itu, konsep muhkam-mutasyābih perlu dielaborasi dan dikembangkan kembali bersama perangkat tafsir lain pada masa kontemporer. Reinventing makna muhkam-mutasyābih dan pengembangannya tentu meniscayakan kontsruksi muhkam-mutasyābih yang berbeda-beda dalam setiap bidang. Hal ini tidaklah menjadi masalah karena jika harus diseragamkan atau digeneralisasi, maka akan kembali jatuh pada jurang spesialisasi makna. Dinamisasi dan pengayaan dialektika ilmu al-Qur'an justru menjadi salah satu manfaat yang diharapkan dalam pengembangan muhkammutasyābih. Semakin luas analisa konseptual yang dilakukan, dengan melibatkan berbagai konsep lain dalam ilmu al-Qur'an maupun disiplin lain, pengembangan konsep muhkammutasyābih sangat berpotensi dapat mendukung dan mewujudkan interpretasi al-Qur'an kontekstual yang tidak mengabaikan nilai-nilai teks yang ada.

\section{Daftar Pustaka}

'Aț̣ār, Hasan bin Muhammad al-. Hāsyiyah al- 'Ațtār 'alā Syarh Jalāl al-Dīn al-Mahalli ‘alā Jam i al-Jawāmi.' Vol. 2. Beirut: Dār al-Kutub al-Ilmiyah, t.t.

Abādī, Majd al-Dīn al-Fairuz. Bașā'ir dzawi al-tamyīz fì Lațâ'if al-Kitāb al- 'Azīz. Kairo: Lajnah Ihyā' al-Turāts al-Islāmī, 1996.

al-Jașșāṣ. Ahkām al-Qur'ān. Beirut: Dār Ihyā' al-Turātas al-`Arab̄̄i, 2000.

Al-Ṭaḥāwī, Abu Ja'far. Ahkām al-Qur'ān al-Karīm. Istanbul: Markaz al-Buhūts alIslāmiyyah al-Tībi; li Waqf al-Diyānah al-Turkī, 1998.

Aṣfihāni, Al-Raghib al-. Al-Mufradāt fì Gharīb al-Qur'ān. Beirut: Dār al-Qalam, 1992.

Bukhārī, 'Alā’ al-Dīn al-. Kasyf al-Asrār Syarh Ușūl al-Bazdawī. Beirut: Dār al-Kitāb alIslāmi, t.t.

Bulqīnī, Jalal al-Dīn al-. Mawāqi' al- 'Ulūm fi Mawāqi' al-Nujūm. Ṭanța: Dār al-Ṣaḥābah li al-Turāts, 2007.

Dimyati, Muhammad Afifudin. 'Ulūm al-Tafsīr; Ușūluhu wa Manāhijuh. Sidoarjo: Lisan Arabi, 2016.

Dzahabi, Husain al-. Al-Tafsīr wa al-Mufassirūn,. Kairo: Maktabah Wahbah, 2000.

Firdausi, Muhammad Anwar. "Membincang Ayat-ayat Muhkam dan Mutasyabih." Ulul Albab Jurnal Studi Islam 16, no. 1 (2015): 80-88. 
Haitsami, Ibnu Hajar al-. Tuhfah al-Muhtāj Syarh al-Minhāj. Vol. 8. Mesir: al-Maktabah al-Tijāriyah al-Kubrā, 1983.

Harbī, Husain bin Ali al-. Mukhtașar Qawā’id al-Tarjīh ‘inda al-Mufassirīn Dār. Kairo: Dār Ibn al-Jawzi, 2006.

Harjanto, Nicolaus Teguh Budi. Islam and Liberalism in Contemporary Indonesia: The Political Ideas of Jaringan Islam Liberal (The Liberal Islam Network). Ohio: The College of Arts and Sciences of Ohio University, 2003.

i, Muhammad `abd al-Mun'īm al-Qi'. Al-Aṣlān fì 'Ulūm al-Qur'ān, 1996.

Ismail, Muhammad Bakr. Dirāsāt fì `Ulūm al-Qur'ān. Kairo: Dār al-Manār, t.t.

Jawzi, Ibn al-. Al-Muṣaffa bi Akaffi Ahl al-Rusūkh min 'Ilm al-Nāsikh wa al-Mansūkh. Beirut: Muassasah Al-Risālah, 1998.

Khādimī, Nūr al-Dīn al-. 'Ilm al-Maqāṣid al-Syarī'ah. Maktabah al-'Abīkan, 2001.

Khalāf, Abd al-Wahab. Ilmū Ușūl al-Fiqh wa Khulāṣah Tārīkh al-Tasyrī'. Mesir: Maṭba'ah al-Madani, 1999.

Kodir, Faqihuddin Abdul. Qirā'ah Mubadalah. Yogyakarta: IRCiSoD, 2019.

Kusmana, Kusmana. “EPISTEMOLOGI TAFSIR MAQASIDI.” MUTAWATIR 6, no. 2 (7 Februari 2018): 206-31. https://doi.org/10.15642/mutawatir.2016.6.2.206-231.

Munawwir, Ahmad Warson. Kamus Al-Munawwir. Surabaya: Pustaka Progresif, 1997.

Mushtafa, Ibrahim, Ahmad Zayyat. Al-Mu'jam al-Wasīt. Kairo: Dar al-Da'wah, t.t.

Mustaqim, Abdul. Argumentasi Keniscayaan Tafsir Maqashidi sebagai Basis Moderasi Islam. Yogyakarta: UIN Sunana Kalijaga, 2019.

Mustofa, Agus. "Memahami Al-Qur'an dengan Metode Puzzle." Surabaya: PADMA Press, 2008.

Najitama, Fikria. "Diskursus Muhkam dan Mutasyabih dalam Tafsir." An-Nidzam: Jurnal Manajemen Pendidikan dan Studi Islam 4, no. 1 (2017): 153-69.

Namlah, Abd al-Karīm al-. Al-Muhadzdzab fì 'Ilm Ușul al-Fiqh al-Muqāran. Riyadh: Maktabah Al-Ruysd, 1999.

Nisa', Ihda Hani'atun. "Pembacaan Tafsir Maqashidi terhadap Keselamatan Agama Selain Islam dalam Al-Qur'an." ILMU USHULUDDIN 7, no. 2 (9 September 2020): 195209. https://doi.org/10.15408/iu.v7i2.16774.

Nugraheni, Yunita. "Perubahan Makna Pada Istilah Ekonomi." VALUE ADDED| MAJALAH EKONOMI DAN BISNIS 2, no. 2 (2006).

Qatādah. Al-Nāsikh wa al-Mansūkh. Beirut: Muassasah al-Risālah, 6.

Qatțān, Mannā' Khalīl al-. Mabāhīts fì 'Ulūm al-Qur'ān. Kairo: Maktabah al-Ma'ārif, 2000 . 
—. Tārikh al-Tasyrì’ al-Islāmi. Kairo: Maktabah Wahbah, 1420.

Rahman, Miftahur. “(PDF) Konsep Muhkam Dan Mutasyabih Dalam Alqur'an Menurut Muhammad 'Abid al-Jabiri." Hermeneuti: Jurnal Ilmu Al-Qur'an Dan Tafsir 12 (2018). https://doi.org/DOI: 10.21043/hermeneutik.v12i1.6072.

"REINVENT | Meaning in the Cambridge English Dictionary." Diakses 25 September 2020. https://dictionary.cambridge.org/dictionary/english/reinvent.

Rifqi, M. Ainur, A. Halil Thahir. "Tafsir Maqasidi; Building Interpretation Paradigm Based on Mashlahah." Millalh: Jurnal Studi Agama 18, no. 2 (2019). https://doi.org/10.20885/millah.vol18.iss2.art7.

Sabt, Khālid al-. Qawā'id al-Tafsīr: Jam'an wa Dirāsatan. Kairo: Dār Ibn 'Affān, t.t.

Sakhāwī, Abu al-Hasan al-. Jamāl al-Qurrā' wa Kamāl al-Iqrā'. Beirut: Dār al-Ma'mūn li al-Turāts, 1997.

Șālih, Șubḥi al-. Al-Mabāhits fì 'Ulūm al-Qur'ān. Beirut: Dār al-Ilm li al-Malāyīn, 2000.

Suyūṭ̂̄, Jalal al-Dīn al-. Al-Itqān fì 'Ulūm al-Qur'ān. Beirut: Dār al-Kutub al-Alamiyah, 2012.

Syāmah, Abū. al-Mursyid al-Wajīz ilā 'Ulūm Tata'allaq bi al-Kitāb al- 'Azīz. Beirut: Dār Shadir, 1975.

Syinqīṭ̂̄, Muhammad Amīn al-. Adlwā' al-Bayān fì Idlāh al-Qur'ān bi al-Qur'ān. Beirut: Dār al-Fikr, 1995.

Țabarī, Abu Ja'far al-. Jāmi' al-Bayān fi Ta'wīl Āy al-Qur'ān. Vol. 2. Beirut: Muassasah Al-Risālah, 2000.

Wahyuddin, M. Saifulloh. "Ulum al-Qur'an Sejarah dan Perkembangannya." Jurnal Sosial Humaniora, 1, 6 (Juni 2013). DOI: 10.12962/j24433527.v6i1.608.

Zarkasȳ̄, Badr al-Dīn al-. al-Burhān fì 'Ulūm al-Qur'ān. Beirut: Dār Iḥyā' al-Kutub al'Arab̄iyah 'Isā al-Bābi al-Halbī, 1957.

Zarqānī, Muhammad Abd al-Aẓ̄m al-. Manāhil al-'Irfān fì 'Ulūm al-Qur'ān. Beirut: Mațba'ah Isa al-Babi al-Halabi, 2000.

Zuhayli, Wahbah Muștafā al-. Al-Tafsīr al-Munīr fì al-Aqīdah wa al-Syarī'ah wa alManhaj. Beirut: Dār al-Fikr al-Mu'āṣir, 1998. 